\title{
Drivers of Customer Value Co-Creation in Travel Services Post Covid-19.
}

\author{
Ankita Bhardwaj ${ }^{*}$, Dr. Sanjeev kumar Sharma** \\ *Ankita Bhardwaj is a senior reserach scholar at University Business School, Panjab University, Chandigarh with keen interest in consumer \\ behaviour, relationship marketing, retailing and experiential marketing. \\ ${ }^{* *}$ Dr Sanjeev Kumar Sharma is a professor in University Institute of Applied Management, Panjab University, Chandigarh, with expertise in strategic \\ management, marketing and international business. \\ DOI: 10.29322/IJSRP.11.01.2021.p10984 \\ http://dx.doi.org/10.29322/IJSRP.11.01.2021.p10984
}

\begin{abstract}
The service dominant(S-D) logic has changed the face of the marketing paradigm. It is based on the premise that customers are no longer the passive receivers of the products or services, but play an active role in the value creation process. For the purpose of this paper the research focus is to examine the influence of perceived ease of use of the mobile technology, involvement with the tourism product, interaction with the service provider and active participation of the consumer on customer value co-creation. To do so customer perspective is taken into consideration and a questionnaire is developed on the basis of an in-depth literature review. In specific tourism industry is taken into consideration as there has been tremendous growth in this sector in the previous years and consumer per-se play a pivotal role in planning and execution of the trip which further is an important part in success of the service provider. Data was collected from tourists/travellers and data was analysed using (SEM)structural equation modelling.SEM analysis revealed that the involvement, perceived ease of use, interactions among tourists and tourism service providers and the active participation of tourists have an impact on co-creation in the tourism industry using mobile devices. As one of the first studies in this area in the field of tourism, this study contributes to the body of knowledge by proposing and empirically testing the model.
\end{abstract}

Index Terms- Co-creation, m-commerce, involvement, active participation, degree of co-creation

\section{INTRODUCTION}

$\mathrm{D}$ uring the past few years, a new paradigm has been increasingly gaining ground within the service marketing literature: the service-dominant (S-D) logic (Vargo and Lusch, 2004, 2008; Yi and Gong, 2013). The principal foundation in the S-D logic is that consumers are not passive respondents to firms' value propositions. Instead, consumers become co-creators of value throughout the consumption process (Xie et al., 2008), while the firms develop, design, manufacture, and deliver resources that facilitate consumers' value creation. Consumers are pivotal in the process of value creation as they work in tandem with the producer, together they create value. (Grönroos, 2011).

The view of customers as co-creators of value is a central idea in the service-dominant logic of marketing, which challenges the view of consumers as passive buyers to see them as actors in the production of personalised offers (Payne et al., 2009; Prahalad and Ramaswamy, 2004; Vargo and Lusch, 2004). The increased digitalization of the economy and the adoption and execution of multi-channel strategies by firms (Verhoef et al., 2015) empower consumers to add a little of themselves in the whole experience and enable mass and multifaceted co-creation (Zhang et al., 2017; Zwass, 2010).

Co-creation is a demand-centric and interactive process wherein at least two willing resource-integrating actors are to be engaged in specific forms of mutually beneficial collaboration that results in value creation for them (Frow, Payne, \& Storbacka, 2011). The foundational idea of customer value co-creation refers to participants creating something in collaboration with or influenced by others (Jaakkola, Helkkula, \& Aarikka-Stenroos, 2015). In the tourism context, the idea of co-creation is particularly relevant because of the following reasons. First, offering unique and memorable customer experiences are of paramount importance for tourism service providers in order to remain competitive. Creating a unique experience involves both customer participation and a connection which links the customer to the experience. Tourism is a personal activity and hence consumers want the experience to be tailor made according to their need and ideas (Pine \& Gilmore, 1998; Shaw et al., 2011). Second, the internet has significantly changed the way customers allocate knowledge about hotels, flights or even destinations. The consumer is more aware of his options and wants to explore all his options to make an informed decision.

New information and communication technologies, such as online booking engines, have transformed the structure of the tourism distribution system into a multi-channel network that raises new challenges for both customers and tourism companies (e.g., travel agencies). The challenges for the consumers are the numerous service providers to choose from and also comparing the quotes from one provider to another. In case of the service providers they need to understand the needs of the consumer and prepare a vacation itinerary by taking care of all the intricacies of the consumer. Third, customers create value not only for themselves and the company, but also for other customers which is due to the fact that they often share their travel experiences in online social networks. Online booking engines and websites that allow customers to post their opinions and reviews about tourism service companies are not only a helpful co-creation tool for customers, but also an important source of marketing information 
about customer experiences for companies (Shaw et al., 2011; Wang \& Fesenmaier, 2004).

\section{RESEARCH GAP AND OBJECTIVES OF THE STUDY.}

The literature documents several recent studies conceptualizing value co-creation in hospitality (e.g., Chathoth et al., 2013)and tourism (Prebensen et al., 2013; Prebensen and Foss, 2011). Empirical evidence of co-creation research in tourism is scarce and a number of research questions are still unanswered. Shaw et al. (2011) were among the first to empirically assess the concept of S-D logic and its implications for tourism management in a hospitality setting. Previous studies have acknowledged experience co-creation as a successful strategy of differentiation against competitors (Schmidt-Rauch \& Nussbaumer, 2011).

The study by Lee (2012) reveals that perceived benefits, subjective norms, and ability to co-create are antecedents of the tourists' intention to co-create. Mathis et al. (2016), instead, focus on the consequences of tourism experience co-creation, showing that satisfaction with co-creation of a tourism experience positively affects the satisfaction with vacation experience and the loyalty to the service provider. Grissemann and Stokburger-Sauer (2012) highlight the company support as an antecedent of the degree of co-creation, and customer satisfaction with the service company, customer loyalty, and service expenditures as consequences. The empirical research on the co-creation in tourism is, therefore, still limited.

In this research, we follow up on calls for further research on customer value co-creation and investigate both theoretically and empirically the influence of involvement, perceived ease of use, interactions among tourists and tourism service providers and the active participation of tourists on co-creation in tourism services.

\section{LITERATURE REVIEW AND DEVELOPMENT OF HYPOTHESIS}

\section{Impact of Covid-19 on tourism industry}

Tourism, which contributes 5.06 per cent in India's GDP (2016-17) is one such industry which has been ignored in this recovery package. The ongoing pandemic, travel restrictions, and the country wide lockdown have brought the entire tourism industry to a standstill, and unlike other sectors, tourism will take longer to recover, especially leisure tourism. This will have a direct impact on states like Uttarakhand, Rajasthan, Kerala, Himachal Pradesh, Goa, Sikkim and other north eastern states which depend extensively on tourism as a source of state revenue.

The Indian tourism industry employs 8.75 crore people (12.75 per cent of the total employed population in 2018-19), such as people from the hospitality industry, tour operators, travel agents, homestay owners, drivers, guides, small traders, artisans and craftsmen among a host of other service providers. The sector also has strong forward and backward linkages to other sectors such as agriculture, transport, handloom, and FMCG to name a few. Disruptions in tourism sector will render many people in unemployed. The food and hospitality sector is already reeling under pressure from high fixed costs and no footfalls. FAITH, a policy federation of associations of tourism and hospitality industry has estimated a loss of Rs 10 lakh crore for the industry due to COVID-19. This will also impact inflow of foreign tourists, which means a drastic fall in foreign exchange earnings which was close to Rs 2,10, 981 crore in Q1-Q3 2019. India is yet to address the concerns of the tourism sector

\section{Post-Lockdown Tourism}

The COVID 19 pandemic has changed the way we live. Now that the restrictions at the state border have been elevated tourism may witness some growth. Many companies have allowed their staff to work from home, others are providing a change of place in the form of working from homestays. Many big tourism and hospitality brands such as Airbnb, OYO, Vista are jumping in with the promise of homestays as an alternative universe during the pandemic. The hotels are also making sure that the safety of the guests is certain. At almost every hotel measure such as sanitizations, use of personal protective equipment by the staff in both F\&B and housekeeping department. Social distancing has become a new normal for the present generation. The airlines and the aviation business are also implementing safety guidelines for the traveler's safety. The airlines and aviation businesses in India are greatly advanced when it comes to infrastructural development and automation. The airports are practicing smart security resolutions, computerized traveler screening systems, automated tray retrieval systems, and RFID tagged trays at the checkpoint screening to reduce wait time for people and increased passenger experience at security checkpoints. AI technology is also increasingly coming into use to provide a connected and enhanced digital experience to air travellers. Thus it is believed that the tourism sector will result to its glory in the coming times and continue to add to the GDP of the country.

\section{Value co-creation}

Co-creation refers to an interactive process involving at least two actors who are engaged in specific forms of mutually beneficial collaboration and resulting in value creation for those actors (Frow et al., 2011,). Co-creation is at the basis of Service Dominant Logic (SDL) that places services instead of products at the center of the economic exchange (Vargo \& Lusch, 2004). According to SDL, a customer is no longer considered a target to reach with positioning strategies but as an active resource who should be involved in the value creation process. With this active role, the customer is able to influence and improve the ultimate experience as he has clarity of his requirements and the service provider designs the service accordingly. The customer can contribute to realizing innovative products and services that can help create memorable experiences (Chathoth, Altinay, Harrington, Okumus, \& Chan, 2013; Gronroos, 2008; Kandampully, Zhang, \& Bilgihan, 2015; Lusch, Vargo. \& O’Brien, 2007; Matthing et al., 2004; Torres, 2016).

\section{Value co-creation via Mobile commerce}

Given the highly interactive character of travel services and the fragmentation of consumption, the S-D logic paradigm has been predicated to be more useful than the traditional paradigms in conceptualizing value creation in travel and tourism (Chathoth et al., 2013). Reflecting today's increasing popularity of mobile technology(Coussement and Teague, 2014), the tourism industry business models have changed by allowing consumers to engage 
more interactively than ever .Consumers can use location-based services and accept only services that fit their preferences, and thus leading to personalized direct interactions. (Grönroos, 2011). The paper investigates the influence of involvement, perceived ease-of-use, interaction and active participation on customer value co creation. These factors are representative of the components that impact on encounters of value co-creation according to the conceptual model of Payne et al. (2009): customer processes, supplier processes and additional sources of brand knowledge

\section{Involvement and co-creation}

The relationship between category involvement and customer co-creation has not been evidenced yet but is a research proposition of France et al. (2015), who suggest that for cocreation to occur customers must have a sufficient level of involvement in the specific category of the brand. Involvement is a motivational variable reflecting the extent to which an activity is personally relevant to the individual (Zaichkowsky, 1994). Payne et al. (2009) suggest that those customers that share values and concerns related to a specific task would be more willing to cocreate; by co-creating, customers embed themselves in the process of learning about the product category. As Nambisan and Baron (2009) state, the more important the product is to a customer, the more he or she has a stake in the co-creation task and, therefore, the more likely he or she is to participate in online co-creation. The level of involvement defines the mode of decision making for the customer. According to the elaboration likelihood model more involved the customer, he will indulge in extended decision making, more inclined towards co-creation to make sure he gets the products/services tailor made to his specifications. From a list of potential motivators to co-create in virtual words, Zwass (2010) identifies passion for a task and learning through co-creation from and with others; these are attributes that belong to the concept of involvement in the product category, Thus, it can be expect that highly involved customers will be likely to undertake online cocreation:

\section{H1: Involvement positively affects customer value co-creation.}

\section{Perceived ease of use and co-creation}

The perceived expertise of the customer, or their selfefficacy related to the task, will also affect the intention to cocreate or the actual co-creation behaviour (Bendapudi and Leone, 2003; Xie et al., 2008). In online co-creation processes, customers have to learn to participate through an online platform. The perceived ease-of-use of a technological system is a variable drawn from the technology acceptance model - TAM (Davis, 1989), which has been widely employed as an antecedent of the usage of a technology for performing a task. Higher perceived ease-of-use of the internet for co-creation will act as an intrinsic motivation to participate as it will reduce the barriers to perform the task

\section{H2: Perceived ease-of-use of the mobile application platform positively affects customer value co creation..}

Interaction between tourists and tourism service providers and customer value co creation.
Payne, Storbacka, and Frow (2008) recognize the fundamental role of interactions and introduce the encounter process as part of their conceptual framework to explain the travel experience of co-creation for customers. The authors define it as a process of interactions and transactions occurring between the tourists and the tourism service providers at the destination during moments of contact in which both parties are involved. According to these authors, there are critical encounters that may positively or negatively influence co-creation. According to Chathoth et al. (2014b), effective communication between tourism service providers at the destination and tourists is an important factor for tourist involvement and consequently for co-creation. Therefore, interaction is considered to be an important factor in experience co creation because firms can achieve a competitive advantage by dialoguing in a personal way with customers at all points of the relationship, these points being the locus of experience co-creation (Prahalad \& Ramaswamy, 2004a). Based on the above discussions, the following hypothesis can be proposed:

\section{H4. The interaction between tourists and tourism service providers has a positive effect on experience co-creation in tourism.}

\section{Active participation and customer value co-creation}

Co-creation presupposes the combination of customers' resources with those of organizations (Chathoth et al., 2016; Hoyer, Chandy, Dorotic, Krafft \& Singh, 2010). According to Andersson (2007), customers contribute to the final step of the production process by combining their resources with those of organizations and co-creating their own experiences, implying the transformation of customers from passive to active partners (Chathoth et al., 2013). Carù and Cova (2007) suggest that customers can be actively or passively involved. Passively, organizations have control over the relationship, whereas active participation allows customers to immerse themselves in an experience, taking responsibility for each step in the process. In other words, in order to actively engage customers, an effort on the part of organizations must be aimed at adopting a customer perspective. In this way, the customers' needs and expectations can be better met (Chathoth et al., 2014b). Prahalad and Ramaswamy (2004a) affirm that experience co-creation is influenced by the active involvement of customers before, during, and after consumption. The challenge for the organizations is actively engaging customers by providing them a space in which they may combine their resources and thereby generate a variety of potential co-created experiences (Ramaswamy \& Gouillart, 2010). The active role of tourists is especially important in the cocreation of tourism experiences because successful experiences should be personalized and require the direct intervention of tourists with their own resources. Thus the hypothesis

H5. The active participation of tourists in the entire experiential process has a positive effect on experience co-creation in tourism.

\section{RESEARCH METHODOLOGY}

\subsection{Context of the study}


The context of the study is the tourism industry because of the enhanced relevance of co creation in tourism and also scarcity of empirical research in the same. For the purpose of integrating mobile commerce with tourism, all the applications available on app store (IOS) /play store(Android)that can serve as a platform for the consumer to co create a travel package were included in the questionnaire. This was done to ascertain the degree of awareness among the users regarding various applications that facilitate customer value co-creation.

\subsection{Research design}

The research hypotheses were tested through a quantitative approach in which data was collected based on a survey due to its suitability with the purpose and nature of the study in question. The focus of the research is on the young travellers who are desirous of exploring new places in the upcoming holidays. The central idea is to comprehend the degree to which the consumer is involved in the arrangement process and not the co-created product itself. More specifically, we focused on the co-creation process rather than on the outcome of this process.

\subsection{Measures}

The constructs are measured by a set of multiple five-point Likert scales ranging from "strongly disagree" (1) to "strongly agree" (5), realized by combining existing scales in the literature. Furthermore, as affirmed by Revilla, Saris, and Krosnik (2014), five-point scales yield better quality data than scales with more points.

The instrument is divided into three sections, where section A asked the qualifying questions such as whether in the last two years, have respondents had planned/booked a holiday package, did they get the holiday package designed as per their own requirements, and did they buy that holiday package online. Section B had questions regarding the constructs, the items of which are adapted from the literature. The scale for involvement was adapted from Novak et al., 2000) and had 5 items. Perceived ease of use was measured using 4 item scale given by Teo, et all 1999. The three items related to the interaction between tourists and tourism service providers at the destination were adapted from Grissemann and Stokburger- Sauer (2012) and Mathis et al. (2016). Three items on the active participation of tourists during their experiences were adapted from Mathis et al. (2016) and Peterson et al. (2005). The degree of co-creation was measured using four items, which were adapted from Grissemann and Stokburger-Sauer (2012).

A list of all the mobile applications that can assist the respondents in co creating the travel package were also included. The third section included demographic questions.

\subsection{Data collection and Data Analysis.}

The data was collected through the self administered questionnaire in a pen and paper format and online survey method. The individuals were asked to answer the questions about the mobile application they co-created with most recently, which they could choose from an extensive list of travel and tourism applications or else write a valid name.

Individuals who had planned/booked a holiday in the last two years and also got the package tailor made according to their own requirements only filled the whole questionnaire. In the present study a total of 186 responses were collected. Since most of the responses were from the online method, the problem of missing values and unanswered questions was taken care of as all the questions were marked compulsory.

The reliability of the constructs under study was checked through cronbach alpha(table I), the value of which was above the acceptable 0.7 .

Table I: Reliability coefficients.

\begin{tabular}{|l|l|l|l|l|l|}
\hline & Involvement & $\begin{array}{l}\text { Perceived ease of } \\
\text { use }\end{array}$ & Interaction & $\begin{array}{l}\text { Active } \\
\text { participation }\end{array}$ & Co creation \\
\hline $\begin{array}{l}\text { No. Of } \\
\text { Dimensions }\end{array}$ & 5 & 4 & 4 & 3 & 4 \\
\hline Cronbach Alpha & 0.804 & 0.899 & 0.930 & 0.755 & 0.794 \\
\hline
\end{tabular}

\section{RESULTS}

The demographic information is summarised in table II. The study results shows that majority of the respondents were from the state of Haryana (49\%) followed by equal participation by Punjab and Chandigarh (18\% each) and Himachal Pradesh (13\%). Most of the respondents were post graduates $(50 \%)$ and belonged to the salaried class $(48.4 \%)$. With regards to travel behaviour $63 \%$ of the respondents travelled with their families, $22.6 \%$ travelled with friends and only $3.2 \%$ travelled alone.

Table II: Demographic information and travel behaviour of respondents.

\begin{tabular}{|l|l|l|}
\hline Variable & Frequency & Percentage \% \\
\hline
\end{tabular}

\begin{tabular}{|l|lr|l|}
\hline Gender & Male & 92 & 49.5 \\
& Female & 94 & 50.5 \\
\hline Age & $15-29$ & 91 & 48.9 \\
& $30-44$ & 72 & 38.7 \\
& $45-59$ & 14 & 7.5 \\
& 60 \&above & 9 & 4.8 \\
\hline State & Haryana & 92 & 49.5 \\
& Punjab & 35 & 18.8 \\
& Chandigarh & & 18.3 \\
& 34 & & 13.4 \\
& Himachal & Pradesh & \\
& 25 & & \\
\hline Education & Undergraduate & 4.8 \\
& 9 & & 37.1 \\
& Graduate & 69 & 50.5 \\
\hline
\end{tabular}




\begin{tabular}{|l|lr|l|}
\hline & Post & graduate & 3.2 \\
& 94 & & 4.3 \\
& Doctorate & 6 & \\
& Others & 8 & \\
\hline Occupation & Salaried & 90 & 48.4 \\
& Business & 25 & 13.4 \\
& Professional & & 11.3 \\
& 21 & & 4.8 \\
& Retired & 9 & 15.1 \\
& Students & 28 & 7 \\
& Others & 13 & \\
\hline Companion & Alone & 6 & 3.2 \\
& Family & 117 & 62.9 \\
& Friends & 42 & 22.6 \\
& Significant other & 7 & 3.8 \\
& Organised group & 5 & 2.7 \\
& Others & 9 & 4.8 \\
\hline Marital status & Never & married & 46.2 \\
& 86 & & 51.6 \\
& Married & 96 & .5 \\
& Widowed & 1 & 1.6 \\
& Divorced & 3 & \\
\hline
\end{tabular}

Before evaluating the structural model, we analyze the measurement model. Following the theoretical guidelines (Hair et al., 1999) we carry out a factorial analysis using structural equations and taking into account four criteria: the significance and value of the factorial loadings, the individual reliability of each item and the model's fit indices.

$\mathrm{CMIN} / \mathrm{DF}\left(\chi_{2} / d f\right)$ is the minimum discrepancy divided by its degrees of freedom; the ratio should be close to 1 for correct models. Wheaton et al. (1977) suggest a ratio of approximately five or less 'as beginning to be reasonable. The measurement model had CMIN/DF =3.161 which is to be considered a reasonable fit.

According to Arbuckle (2005), the RMSEA value of about 0.05 or less would indicate a close fit of the model in relation to the degrees of freedom. In this measurement has a RMSEA=.073 which again shows a reasonable fit.

The CFI value should be between 0 and 1 . A value close to 1 indicates a very good fit. In the measurement model CFI=.801. The TLI value lies between 0 and 1 , but is not limited to this range. A value close to 1 indicates a very good fit .A value greater than 1 indicates an over-fit of the model. Here TLI=.768. The GFI value is always less than or equal to 1 . A value close to 1 indicates a perfect fit. The GFI for the measurement model was .736. Since the indices were close to the cut off and the model was a reasonable fit, it was considered for further analysis.

The structural model present appropriate values in general for the goodness of fit indices( $\mathrm{CMIN} / \mathrm{Df}=3.958$, GFI=.666 , $\mathrm{CFI}=.713, \mathrm{RMR}=.219, \mathrm{RMSEA}=.078, \mathrm{TLI}=.682$ )

Table III has the correlation coefficients which is a statistical measure that calculates the strength of the relationship between the relative movements of two variables. The values range between 1.0 and 1.0

Table III: Correlation coefficients.

\begin{tabular}{|l|l|l|l|l|l|}
\hline & Involvement & $\begin{array}{l}\text { Perceived ease } \\
\text { of use }\end{array}$ & Interaction & $\begin{array}{l}\text { Active } \\
\text { participation }\end{array}$ & Co creation \\
\hline Involvement & 1 & $.488^{* *}$ & $.244^{* *}$ & $.467^{* *}$ & $.467^{* *}$ \\
\hline Perceived ease of use & $.488^{* *}$ & 1 & $.436^{* *}$ & $.462^{* *}$ & $.425^{* *}$ \\
\hline Interaction & $.244^{* *}$ & $.436^{* *}$ & 1 & $.514^{* *}$ & $.270^{* *}$ \\
\hline Active participation & $.467^{* *}$ & $.462^{* *}$ & $.514^{* *}$ & 1 & $.576^{* *}$ \\
\hline Co creation & $.467^{* *}$ & $.425^{* *}$ & $.270^{* *}$ & $.576^{* *}$ & 1 \\
\hline
\end{tabular}

** All the values are significant.

The correlation coefficients among the variables were significant. There was a need to assess the impact of variables on co creation and also explain the level of variation each antecedent has on co creation. The impact of each variable on co-creation is reported in table IV. The independent variables are perceived ease of use, involvement, interaction and active participation and co creation is the dependent variable.

Table IV: Impact of antecedents on co creation. Result of regression analysis.

\begin{tabular}{|l|l|}
\hline Independent Variables. & Regression Results \\
\hline
\end{tabular}

This publication is licensed under Creative Commons Attribution CC BY

\begin{tabular}{|l|l|}
\hline Involvement & $\begin{array}{l}\mathrm{R}^{2}=.218, \quad \mathrm{~F}(1,184)=51.234, \\
\mathrm{p}<.01\end{array}$ \\
\hline Perceived ease of use & $\begin{array}{l}\mathrm{R}^{2}=.181, \quad \mathrm{~F}(1,184)=40.570, \\
\mathrm{p}<.01\end{array}$ \\
\hline Interaction & $\begin{array}{l}\mathrm{R}^{2}=.251, \quad \mathrm{~F}(1,184)=61.580, \\
\mathrm{p}<.01\end{array}$ \\
\hline Active participation. & $\begin{array}{l}\mathrm{R}^{2}=.331, \quad \mathrm{~F}(1,184)=91.137, \\
\mathrm{p}<.01\end{array}$ \\
\hline
\end{tabular}

\section{FINDINGS}

The research model had contemplated four independent variables and their impact on co-creation : involvement as an 
exponent of individual characteristics that affect customer processes, and variable that was specific to the online context perceived ease-of-use of the online co-creation platform, the consumer related variables being interaction and active participation.

Taking into consideration the above mentioned variables, it was found that involvement in planning and designing the whole trip had a significant impact on value co creation. Involvement in planning explains $21.8 \%$ variation in co creation and interaction of the tourist and the tourism service provider has the most impact on co-creation explaining $25.1 \%$ variation. Other variables that explain major variation in co creation are active participation by the consumer in deciding the intricacies of the trip was also significant (explain 33.1\% variation in co creation) and perceived ease of use (explain 18.1\% variation in co creation).The structural model specifying the direction of the relationship among the variables gave a reasonable fit of the model.

The relationships between "active participation of the tourist during the experience" and "interaction between the tourist and tourism service providers". was not hypothesized in the proposed model but arose to obtain a more adequate model. This is an important finding because it highlights that the consumers who actively participate in the co creation are more inclined to have longer interactions with the service provider. This further gives ample opportunity to the service provider to foster long term relationships with the customers.

The respondents surveyed mobile applications to design their holiday package and get the best deal. The mobile applications used by most of the respondents were make my trip, Goibibo, trip advisor, tripito, bookings.com.

\section{Implications}

This study has relevant implications for firms that are interested in developing and managing online co-creation activities with customers. The results also provide managers some hints on how to stimulate co-creation behaviours. First of all, they should design a user-friendly co-creation platform as perceived ease-of-use is explicating online co-creation to a high degree; then, they should communicate how easy it is to perform co-creation online as a low perceived ease-of-use is a barrier that may be related to poor design or a lack of customer familiarity with the online co-creation task. The active participation of tourists is the main antecedent of co-creation in tourism. The degree of cocreation has improved due to tourists' decision to challenge their skills and abilities during travel, adoption of a hands-on approach, and active involvement in the activities provided by the destination.

The mobile applications surveyed by the respondents were not necessarily used to make payments, as 71 respondents $(38 \%)$ did not buy the package online but got the package designed. So the marketers can use this information to persuade consumers to make online payments as well.

\section{Limitations and Future Direction.}

Although this study offers considerable insights into cocreation in a tourism service context, it entails a few limitations that should be acknowledged. The research was purposely limited to the travel and tourism sector as this is one of the leading sector that uses digital communication channels and, thus, is also a good exponent of online co-creation. Notwithstanding, future research could explore additional sectors to increase the validity of the results. This study was conducted with data only from a similar type of population that is the young travellers. This study can be taken forward to compare the results among different age groups to comprehend as to which age group is more inclined towards cocreation. This current model was designed to be parsimonious, to create a core theoretical foundation that can be easily operationalized in various value co-creation contexts. Further research could construct more complex models in order to explain the complex relationships leading to the co-creation and assessment of value in hospitality.

\section{REFERENCES}

[1] Andersson, T. D. (2007). The tourist in the experience economy. Scandinavian Journal of Hospitality and Tourism, 7(1), 46e58.

[2] Bendapudi, N. and Leone, R.P. (2003), "Psychological implications of customer participation in coproduction", Journal of Marketing, Vol. 67 No. 1, pp. 14-28.

[3] Carù, A., \& Cova, B. (2015). Co-creating the collective service experience. Journal of Service Management, 26(2), $276 \mathrm{e} 294$.

[4] Chathoth, P. K., Altinay, L., Harrington, R. J., Okumus, F., \& Chan, E. S. W. (2013). Coproduction versus co-creation: A process based continuum in the hotel service context. International Journal of Hospitality Management, 32 $11 \mathrm{e} 20$.

[5] Chathoth, P. K., Ungson, G. R., Altinay, L., Chan, E. S. W., Harrington, R. J., \& Okumus, F. (2014b). Barriers affecting organizational adoption of higher order customer engagement in tourism service interactions. Tourism Management, 42, 181e193.

[6] Chathoth, P. K., Ungson, G. R., Harrington, R. J., Altinay, L., \& Chan, E. S.W. (2016). Cocreation and higher order customer engagement in hospitality and tourism services. A critical review. International Journal of Contemporary Hospital Management, 28(2), 222e245.

[7] Chathoth, P. K., Ungson, G. R., Harrington, R. J., Altinay, L., Okumus, F., \& Chan, E. S. W. (2014a). Conceptualization of value co-creation in the tourism context. In N. K. Prebensen, et al. (Eds.), Creating experience value in tourism (pp.33e47). Wallingford: CAB International.

[8] Chathoth, P., Altinay, L., Harrington, R.J., Okumus, F., Chan, E.S.W., 2013. Co production versus co-creation: a process based continuum in the hotelservice context. Int. J. Hosp. Manag. 32 (1), 11-20.

[9] Chathoth, P.K., Ungson, G.R., Altinay, L., Chan, E.S.W., Harrington, R., Okumus, F.,2014. Barriers affecting organisational adoption of higher order customer engagement in tourism service interactions. Tour. Manag. 42, 181193.

[10] Coussement, M.A., Teague, T.J., 2014. The new customer-facing technology: mobileand the constantly connected consumer. J. Hosp. Tour. Technol. 4 (2), 177-187.

[11] Etgar, M. (2008). A descriptive model of the consumer co-production process.Journal of the Academy of Marketing Science, 36(1), 97e108.

[12] Frow, P., Payne, A., \& Storbacka, K.. (2011). Co-creation: A typology and conceptualframework. Presented at the Australian \& New Zealand Marketing Academy conference ANZMAC 2011, Perth, 2011 (pp. e). Perth, Australia. work. Presented at the Australian \& New Zealand Marketing Academy conference ANZMAC 2011, Perth, 2011 (pp. e). Perth, Australia.

[13] Gr€onroos, C. (2008). Service Logic Revisited: Who Creates Value? And Who Co- Creates? European Business Review, 20(4), $298 \mathrm{e} 314$.

[14] Grissemann, U. S., \& Stokburger-Sauer, N. E. (2012). Customer co-creation of travel services: The role of company support and customer satisfaction with the cocreation performance. Tourism Management, 33(6), 1483e1492.

[15] Grönroos, C., 2011. Value co-creation in service logic: a critical analysis. Mark.Theory 11 (3), 279-301.

[16] Heitmann, M., Lehmann, D.R. and Herrmann, A. (2007), "Choice goal attainment and decision and consumption satisfaction", Journal of Marketing Research, Vol. 44 No. 2, pp. 234-250. 
[17] Hoyer, W. D., Chandy, R., Dorotic, M., Krafft, M., \& Singh, S. S. (2010). Consumer cocreation in new product development. Journal of Service Research, 13(3), 283e296.

[18] Jaakkola, E., Helkkula, A., \& Aarikka-Stenroos, L. (2015). Service experience cocreation: conceptualization, implications, and future research directions. Journal of Service Management, 26(2), 182e205. Journal of Hospitality and Tourism, 7(1), 46e58

[19] Kandampully, J., Zhang, T., \& Bilgihan, A. (2015). Customer loyalty: A review and future directions with a special focus on the hospitality industry. International Journal of Contemporary Hospitality Management, 27(3), $379 \mathrm{e} 414$.

[20] Lee, G. (2012). Modeling consumers' co-creation in tourism innovation. Temple University.

[21] Li, X., Petrick, J.F., 2008. Tourism marketing in an era of paradigm shift. J. TravelRes. 46 (3), 235-244

[22] Mathis, E. F., Kim, H. L., Uysal, M., Sirgy, J. M., \& Prebensen, N. (2016). The effect of co-creation on outcome variable. Annals of Tourism Research, $57,62 \mathrm{e} 75$.

[23] Payne, A., Storbacka, K., Frow, P. and Knox, S. (2009), "Co-creating brands: diagnosing and designing the relationship experience", Journal of Business Research, Vol. 62 No. 3, pp. 379-389.

[24] Peterson, C., Park, N., \& Seligman, M. E. P. (2005). Orientations to happiness and life satisfaction: The full life versus the empty life. Journal of Happiness Studies, 6,

[25] Pine, B. J., \& Gilmore, J. (1998). Welcome to the experience economy. Harvard Business Review, 76, 97e105.

[26] Prahalad, C.K. and Ramaswamy, V. (2004), "Co-creation experiences: the next practice in value creation", Journal of Interactive Marketing, Vol. 18 No. 3, pp. 5-14.

[27] Prebensen, N.K., Foss, L., 2011. Coping and cocreation in tourist experiences. Int. J.Tour. Res. 13 (1), 54-57.

[28] Ramaswamy, V., \& Gouillart, F. (2010). Building the Co-Creative enterprise. Harvard

[29] Revilla, M. A., Saris, W. E., \& Krosnick, J. A. (2014). Choosing the number of categories in agree-disagree scales. Sociological Methods \& Research, 43(1), 73-97.

[30] Schmidt-Rauch, S., \& Nussbaumer, P. (2011). Putting value co-creation into practice: A case for advisory support. In Proceedings of the19th European conference on information systems, ECIS 2011. Helsinki, 2011. Helsinki, Finland. Service Management, 26(2), $276 \mathrm{e} 294$.

[31] Shaw, G., Bailey, A., \& Williams, A. (2011). Aspects of service-dominant logic and its implications for tourism management: examples from the hotel industry. Tourism Management, 32(2), 207e214.

[32] Torres, E. N. (2016). Guest interactions and the formation of memorable experiences: An ethnography. International Journal of Contemporary Hospitality Management, 28(10), 2132e2155

[33] vanDoorn, J., Lemon, K. N., Mittal, V., Nass, S., Pick, D., Pirner, P., et al. (2010). Customer engagement behavior: theoretical foundations and research directions. Journal of Service Research, 13(3), 253e266.

[34] Vargo, S. L., \& Lusch, R. F. (2004). Evolving to a new Dominant Logic for marketing.
[35] Vargo, S.L., Lusch, R.F., 2004. Evolving to a new dominant logic for marketing. J.Mark. 68 (1), 1-17.

[36] Vargo, S.L., Lusch, R.F., 2008. Service-dominant logic: continuing the evolution. J.Acad. Mark. Sci. 36, 1-10.

[37] Verhoef, P.C., Kannan, P.K. and Inman, J.J. (2015), "From multi-channel retailing to Omni-channel retailing: introduction to the special issue on multichannel retailing”, Journal of Retailing, Vol. 91 No. 2, pp. 174-181.

[38] Wang, X., Li, X., Li, Q., \& Peng, L. (2014). Intention of sharing travel experiences on social media: Motivations and the moderating effects of face orientation. In Presented at the 25th Australasian conference on information systems (2014).

[39] Wheaton, B., \& Muthen, D. F. (1977). ALWIN, and GF SUMMERS (1977)“Assessing reliability and stability in panel models," pp. 84-136 in DR Heise (ed.).

[40] Xie, C., Bagozzi, R.P. and Troye, S.V. (2008), "Trying to prosume: toward a theory of consumers as cocreators of value", Journal of the Academy of Marketing Science, Vol. 36 No. 1, pp. 109-122.

[41] Xie, C., Bagozzi, R.P., Troye, S.V., 2008. Trying to prosume: toward a theory ofconsumers as co-creators of value. J. Acad. Mark. Sci. 36 (1), 109-122.

[42] Yi, Y., Gong, T., 2013. Customer value co-creation behavior: scale development andvalidation. J. Bus. Res. 66 (9), 1279-1284

[43] Zaichkowsky, J.L. (1994), "Research note: the personal involvement inventory: reduction, revision, and application to advertising", Journal of Advertising, Vol. 23 No. 4, pp. 59-70

[44] Zhang, M., Hu, M., Guo, M. and Liu, W. (2017), "Understanding relationships among customer experience, engagement, and word-of-mouth intention on online brand communities: the perspective of service ecosystem", Internet Research, Vol. 27 No. 4, pp. 839-857.

[45] Zwass, V. (2010), "Co-creation: toward a taxonomy and an integrated research perspective",International Journal of Electronic Commerce, Vol. 15 No. 1, pp. 11-48.

[46] Zwass, V. (2010), "Co-creation: toward a taxonomy and an integrated research perspective", International Journal of Electronic Commerce, Vol. 15 No. 1, pp. 11-48.

\section{AUTHORS}

First Author - Ankita Bhardwaj, Ankita Bhardwaj is a senior reserach scholar at University Business School, Panjab University, Chandigarh with keen interest in consumer behaviour, relationship marketing, retailing and experiential marketing.

Second Author - Dr. Sanjeev kumar Sharma, Dr Sanjeev Kumar Sharma is a professor in University Institute of Applied Management, Panjab University, Chandigarh, with expertise in strategic management, marketing and international business. 